\title{
LANGUAGE CONCEPTS OF THE IMAGE OF UKRAINE IN IVAN PEREPELIAK'S POETRY
}

\author{
Viktoriia Gorenko \\ Postgraduate Student, H. S. Skovoroda Kharkiv National Pedagogical University, Ukraine \\ e-mail: viktoriiagorenko@gmail.com, orcid.org/0000-0003-2697-2214
}

\begin{abstract}
Summary
The article embodies the idea to explore the linguistic concepts of the image of UKRAINE in the language of Ivan Mikhailovich Perepeliak. The concept of UKRAINE, according to our research, is the semantic center of the cognotype WORLD and is represented by the paradigm of the concepts TERRITORY, NATIVE LAND, SLAVED LAND, WILL, STATEHOOD, SPIRITUAL WORLD in relation to its history and expression. For Ivan Perepeliak, the space of his native land is associated with favorite rivers, cities, villages, trees, flowers, in a word, concepts that are connected with the Ukrainian space. Therefore, in the bosom of this artistic and semantic plane, attention is focused on the love of freedom, self-affirmation of independence, the spirituality of the country as a living being. The geographical space of Ukraine is perceived by the author as a territory within modern borders and marked by an organic component of Europe. Awareness of Ukraine as a European state is marked by complexity and ambiguity in the worldview and aesthetic views of Ivan Mikhailovich Perepeliak.
\end{abstract}

Keywords: concept, conceptosphere, anthroponymicon, toponyms, verbalization, idiostyle.

DOI: https://doi.org/10.23856/4204

\section{Introduction}

For each person, the main thing in life is the place where he was born, grew up, created, took care of his well-being and other people close to him. Little Motherland, native land, land of parents and grandparents constantly remind of involvement in the symbolic image that echoes in the hearts of many generations, reminds descendants to be vigilant and loyal, to love and create beauty, uniqueness, independence. And every master of the word especially feels this sacred belonging to the native land. Each of them interprets the concept of this image-symbol in its own way. We mean Ukraine, which is not only a geographical area, but also forms a number of images that every artist uses in works of art. The so-called toponym "Ukraine" is not only used as a linguistic image of the world of Ivan Perepeliak, but also finds expression in the lexical palette of meanings in geographical and historical names in derived words due to the rich association of the poet. As we noted above, I. Perepeliak addressed this image in almost every one of his poems. For him, Ukraine was not only a part of the world, but also a part of himself: “Ukraine! / On your sunny day / Happiness was destined for us alone”. Examining the poet's linguistics, we single out among his semantic cycles several that characterize him specifically as a person: early works of Perepeliak - a soldier, Perepeliak - a sixtier, Perepeliak - a historian, Perepeliak - a nature lover, Perepeliak - a philosopher, a citizen, Perepeliak - a patriot, etc. Let's not forget that Ivan Perepeliak is a combination of a man and a poet, which gave impetus to the emergence of many diverse works of art, which remain relevant today. Aim of work: based on the study of works by Ivan Mikhailovich Perepeliak, we plan to explore the linguistic concept of UKRAINE and find out what place it occupies in the language of the artist. Achieving the 
goal involves the following tasks: 1) to identify the use of the toponym UKRAINE in the works of the poet and to trace the role it plays; 2) to find out the prevalence of this concept in the analyzed texts in different periods of the work of Ivan Mikhailovich Perepeliak. Research methods and techniques: The main research methods are the method of sampling the actual material, observation of the language material, descriptive method with methods of interpretation, linguistic and stylistic analysis, analytical and synthetic processing of the material.

\section{The linguistic image of Ukraine for Perepeliak - the warrior - internationalist}

It is largely formed by the contextual opposition of the artistic and semantic sphere NATIVE LAND - FOREIGN LAND. The conceptual toponym is represented in the works of this period through a variety of concepts: "I met my" Poltava "among them (Perepeliak, 2013: 69); "On this bank, as on the Sula / Clouds lay blue bridges" (Perepeliak, 2013: 70); "In haze / My whitewalled house hid... / Having felt the malt of warm arable land... I I have never seen him like this, / As in my Poltava side" (Perepeliak, 2013: 71); "Mom! Here the sun is like in our village" (Perepeliak, 2013: 70); "And tears burned my soul as they kissed the earth from Obolon" (Perepeliak, 2013: 71); "At the other end of the planet, the mother is not asleep at this time... / They can't sleep late / Havana and Obolon" (Perepeliak, 2013: 72); "So cold in the hot tropical nights! / Nothing warms me here" (Perepelyak, 2013: 74); "Endured in the deep... / What will happen to me in this hell?../ Wash your face in the warm Gulf Stream" (Perepeliak, 2013: 75); "Strange island of Santa Maria / Grows out of the fog like a dream"; (Perepeliak, 2013: 76) "The triangle of death, they say, and the sea of voodoo... / We enter the infernal black circle" (Perepeliak: 77). It can be seen how the linguo-mental structure of Ukraine (native land) represents national archetypes, which are even more sharply perceived by the author during his military service in Cuba. In poetry, the author shows the concept of UKRAINE, due to geographical space, so the use of the adverb "there" is subconsciously opposed to the word "here". From this point of view, the artistic canvas of the "Cuban Poem" is interesting, where the artist acquaints the Ukrainian reader with many toponyms, anthroponyms, hydronyms and other images-signs, so close to his native Ukraine: "Granma is the first. / The path of intercession is wobbly... / And America's chosen one came out against the aristocrat; That Guevara is a legend! / Che Guevara - no? (Perepeliak, 2013: 87); On Playa Chiron gurgled / Yesterday another battle; It seemed that all of Cuba, / unfinished in battle, / hid in the mountains; But already surrounded this island / in the sea armada / Other people's ships (Perepeliak, 2013: 89); As the trail breaks off / on a cliff-/ Thorny / in the Sierra Maestra's way (Perepeliak, 2013: 90); I am a "condottiere of the twentieth century"... I flee to the mountains, / as to a battlefield, / I take your rage with a rifle (Perepeliak, 2013: 91); I leave you the day of judgment for Vietnam, / Where consolation was sought in the cradle (Perepeliak, 2013: 92).

Let's agree that the geographical space in the poetic language of Ivan Perepeliak is multidimensional in the first period of creativity and during military service on the Island of Freedom, because Ukraine is a land far from the lyrical hero, and therefore we see a clear verbal distinction "I'm here" - "Ukraine there". Speaking about the idiosyncrasy of Perepeliak-post-sixtier, it is necessary to focus on works about the homeland, which appears in the image of the fatherland, because the poet never separated the concept of Ukraine from his native land, but on the contrary, depicted it in the magnificent beauty of nature. An important conceptual place in the system of national symbols is occupied by a number of traditional talismans: "Barefoot-trampled path / I will not lose my grandfathers in the field" (Perepeliak, 2013: 4); "I carry the pedigree of corn... / Listen to the anxieties of the earth / I have gained the highest right by labor" (Perepeliak, 2013: 4); "Since childhood, I learn to cherish bread" (Perepeliak, 2013: 7). 


\section{Ivan Perepeliak - a real nature lover}

The unique magnificent beauty of nature with its endless fields, flooded rivers and lakes, mighty forests and gardens with great love and respect is depicted in the texts of Perepeliak a nature lover. After all, the slogan: "To love nature means to love the Motherland" fully corresponds to his poetic credo. As we have already noted above, the Ukrainian landscapes of the famous master are mostly summer and spring, and therefore the concept of UKRAINE is realized in many poems-landscapes as an independent awakening of the consciousness of every Ukrainian.

The semantic images of the village of Obolon and the river Sula became symbolic signs of the poet's homeland: "Obolon is a land where the May blizzard drifts, / Gardens glow with white color. / In the evening the cherry wing rises, / Throws silver on your tracks... And Sula is in infinite distances / Honey rolls summer". The ecological worldview of the artist is verbalized in the semantic plane NATURE OF UKRAINE with the help of words meaning the names of birds, trees, plants, which are common in our region. The polarity of Perepeliak's poems is complemented by landscape sketches of natural phenomena, which convey the mood of the heroes: "clouds, wind, rain".

\section{Perepeliak - historian}

Poetry and poems dedicated to our history and culture are seen as dominant in the linguistic and mental interpretation of Ukraine. Perepeliak, a historian, singles out the image of a brave, courageous defender of his state in the semantic sphere MAN - PEOPLE, which contains the components of COSSAKS, FIGHTERS, SINGERS, EXILES, PATRIOTS. We have already analyzed a number of portrait poems, it is appropriate to recall once again these immortal names of outstanding figures of history, culture, literature: "A high wave rolled over my soul - And I was fascinated by the history of Ukraine./ He studied the Cossack past, / Ukraine - Russian relations / of the Hetman period..." (Perepeliak, 1983: 26). Perfect knowledge of the history of his native land contributed to the emergence of a number of large poetic texts, where Ivan Perepeliak plays the role of a witness and a direct participant in these important events. We mean his poems "Cossack Monastery", "Rebellion", "The Last Love of the Hetman", where the author verbalizes the semantic levels "love for Ukraine", "love for the people", "love for the native land" in a number of texts: "the lands of good we do not seek, / Now we Ukraine - / Mother of God; In the battle / I fell in love with the songs of Ukraine./ She seemed to me like a lover" (Perepeliak, 2013: 54); "Above the Seversky Donets - may there be peace! Let's build a Cossack monastery, / To hide in robes from Siberia..." (Perepeliak, 2013: 56).

The reader learns about the events taking place on the territory of modern Kharkiv region: "They went fishing at night, / They said: - Let's go for a walk to Zmiyiv" (Perepeliak, 2013: 58); "Chuguiv is already feverish / Who saw where Anna went" (Perepeliak, 2013: 62).

Ivan Perepelyak verbalizes the poetic image of the insurgents in the images of the poem "Rebellion", which tells about the uprising of the Cossacks in the village of Turbai in the Poltava region.

"Turbayevtsi-Cossacks" are depicted in a chain of dynamically changing paintings by means of internal dramatic tension, raging representation in the dialogues of the characters. The poet - a connoisseur of history in his own way reproduces the events of Turbayev as the last Cossack uprising and compares it with other movements led by Nalyvayko, Ostryanitsa, 
Mazepa, Gonta and Zaliznyak. The symbolic image of Ukraine is a key for the insurgents: "Why loud slave shackles! / You swore to God in the Sich veil: / They will not kneel before anyone, / Ukraine was for your prayer!” (Perepeliak, 2013: 154); "Koshov said: / - Poplars stared at you. / Return to Ukraine, / You haven't been waiting for January for a long time. I We went after death / to restore the Cossack will"; (Perepeliak, 2013: 170). Ivan Perepelyak artistically realizes the concept of UKRAINE as a metonymy: "Then there would be changes for the better, / And now everyone is laughing at Ukraine; Moscow bought him with sables, I That's why he dances in front of Muscovites" (Perepeliak, 2013: 247); "The Muscovite became worse than the janissary; Has Peter already felt the danger? / Why is he pushing Ukraine into hell?; It is said that he found support in England, / To hand over Ukraine to Lord Marlboro" (Perepeliak, 2013: 248-249). Oppositionally, through the artistic background of the poem, Ivan Perepelyak, along with living characters, represents the relationship between toponymic concepts: "On the second day, Moscow: / What do we need these Ukrainians for? / resorted to slander" (Perepeliak, 2013: 243); "And here Moscow is already pushing Ukraine / to go to war with the Swedes" (Perepeliak, 2013: 244); "And, Hetman, something needs to be done here - I The Cossacks do not want to serve Moscow" (Perepeliak, 2013: 245); "And how much more will Moscow oppress? / No, we can't live like that; We will make Kyiv a fortress / Let there be no fear of Sweden there"(Perepeliak, 2013: 246).

As we see, a poetic image of Ukraine undergoes a historical perspective of artistic conceptualization, with Perepeliak-historian giving him the features of personalized individuality, perceived in the context of the author's search, and the convergence of the author's self with history and the reality of life in the semantic plane UKRAINE - HISTORY.

Own views on the course of history are presented in other works of verbal creativity. We see before us a whole galaxy of prominent figures for whom Ukraine is the main meaning of life. Dmytro Vyshnevetsky Baida: "It was as if a black cloud had fallen from the sky. / The Tatar invasion is rolling again: / How is Ukraine defending us?" (Perepeliak, 2013: 33); "For the tears of Ukraine-punishment for all, / We will take revenge, as it is, Sich; The last thing I shout at this moment from the top of the pain: / "Hey, brothers - Cossacks, save Ukraine!'; You will defend Ukraine without me" (Perepeliak, 2013: 34-35); Ivan Mazepa: "Save yourself, baby Ukraine! Tsar Peter / Preparing to quarter you; Go to the Swede, Ukraine, or die" (Perepelyak: 42); Philip Orlyk: "And I would stand shoulder to shoulder with them ... / To stir up the dormant Ukraine again”" (Perepeliak, 2013: 43); Pavlo Polubotok: "Ukraine is crying in my heart, I am ready to die for it"; Sviatoslav-Zavoyovnyk: "Therefore, on the first page / In the history of the Great Ukrainians" (Perepeliak, 2013: 45); Petro Kalnyshevsky: "And on you - be damned that date! - Giving January to a bad soldier" (Perepeliak, 2013: 46); Ivan Vyhovsky: "It is taken for Ukraine in disarray - / Yes, it does not seem as if he is incompetent"; Oleg Olzhych: "I came to this world / By order / of the Great Family, / And you, / Told the executioner, / In Ukrainea hoax; Ours should become / Self-government! / Completely Polish, / Moscow, / German... / Ukraine - for Ukrainians!” (Perepeliak, 2013: 185); Olena Teliga: “- You're scaring, me the executer - I'm laughing. - / I'm not afraid to die for Ukraine” (Perepeliak, 2013: 189); Mykola Gogol: "A new harvest awaits me in Kyiv, - / I will write my history of Ukraine there" (Perepeliak, 2013: 203); Guild: "I rushed to fly with an arrow! / Home! Even on the slopes! I To Ukraine” (Perepeliak, 2013: 266); M.S. Khrushchev: "All Ukraine dies in need, / A terrible feast is celebrated by Asmodeus" (Perepeliak, 2013: 360); Ukrainian homers: "But here is Moscow: To glorify Ukraine again / and show people the hell of Moscow... And here is Moscow: Change is needed! / There will be no enchantment of Ukraine, - / It's time to break up new art” (Perepeliak, 2013: 380). 


\section{Perepeliak - philosopher}

For Perepeliak, a philosopher, the poetic image of Ukraine appears in the prism of complex philosophical issues, which include freedom and slavery, truth and lies, the presence of two heroes, I and YOU, who agree that will and happiness are not accidental. In the study of I. Perepeliak's idiosyncrasy, we focus on the organic combination of the harmony of human coexistence with the search for God's presence in our earthly world. Like the Man who builds a temple in his soul and around himself, every Ukrainian feels like the creator of everything new, useful, mental, traditional in building the independence of the Ukrainian state. An interesting paradigm MAN - UKRAINIAN, TEMPLE - UKRAINE is an artistic parallelism in the linguistic and poetic interpretation of Perepeliak's linguistic consciousness, so the purpose of our study is to determine the level of inner feelings of the poet, who in his white pentagonal the third reproduces the conflict, and in the final - finds harmony or points the way to it. Interesting from this point of view is the poem "Yudol of Cry", where the main theme is the motive of overcoming mental chaos. In our opinion, poetry clearly outlines the difficult fate of Ukrainians in the use of words, superstition and chaos of their souls, which act as a "painful nerve", thoughtlessness, humility, an unhappy path to the future. I want to believe that the native language will make us Ukrainians in Ukraine. The concept of UKRAINE is actualized in the artistic and semantic content of UKRAINE-PROPHETS in the poem "Moses": "God's chosen one is the highest of awards! / You are a leader - this is not an easy plan. / You must bring the people out of captivity, / Who are ready to listen to the memorial service..." (Perepeliak, 2013: 269); "To remove the seal of a slave from your forehead, / You must cross the desert without measure!; In the eyes of the slaves you were hardly God, / Who knows how to have mercy and punish" (Perepeliak: 269).

\section{Perepeliak - believer}

Speaking of Perepeliak-believer, it is necessary to correctly interpret the address of the master of the word to the image of God or to the problem of seeking God. We are not talking about the use of many anthroponyms taken from the Scriptures, including Christ, Moses, Mary, as well as the names of other characters of the negative plan - Cain, Judas, Pilate. The position of the poet Perepeliak is reduced to the central dogma according to which God is used in three guises: God the Father, God the Son, God the Holy Spirit. This trinity of God's thinking is reduced to the use of sacred vocabulary in many works of the artist, and what is interesting and instructive - I. Perepeliak turns to the Christian God. Before us is the poem "Hryhoriy Skovoroda" (by the way, I. Perepeliak still has a dramatic poem of the same name), where the most active artistic and semantic content of the poet's language is realized. GOD-CREATOR, DEPUTY: "Clear from sins - to stand before God" (Perepeliak, 2013: 292); "Sincere thanks to God for the fact that / He made what is necessary easy, / It is difficult for us unnecessary...; Knowing yourself, you know God, / And this is the greatest happiness in the world" (Perepeliak, 2013: 296); "Happiness, happiness, you are always from God / And you always give yourself to everyone for free" (Perepeliak, 2013: 295). The words addressed to the God-protector are represented in the paradigm Kingdom of God, King of the soul, God's Spirit: "Kingdom of God / First of all in the heart! Let everyone know this, / Choosing the spiritual orbit" (Perepeliak, 2013: 294); "Knowing yourself, you seem to go up the mountain, / In your soul you will see the kingdom of God" (Perepeliak, 2013: 296); "He will straighten your thoughts to heaven, / And will heal your consciousness from diseases as it should, / He - the King of the soul - greets despair!.." 
(Perepeliak, 2013: 297); "But isn't it time to stop, / Not to drown in the mud, / And to know the Spirit of God in yourself?". Rereading the lines of Ivan Perepeliak's poetic works, you are once again convinced of his devotion to Christianity that the Lord is and will be the patron saint of Ukraine, so the poet's appeals are full of pity and supplication: "Oh God, look! Already patience is over! / Life has become bitter for wormwood. / How many sins and sins do I have? / Show them and give an answer!" (Perepeliak, 2013: 280); "O Lord, for what is the message, I What sins are you looking for in me?" (Perepeliak, 2013: 280). Perepeliak's language is characterized by the so-called "humanization" of God: "God gave and God took away - never defile / His blessed name" (Perepeliak, 2013: 276). The deed of the Most High can be seen from the following lines: "Well," God shuddered, "your word is terrible. / And again the Lord succumbed to Satan" (Perepeliak: 277). In desperation, the author paints a real picture of modern life (meaning Ukraine): "I saw a world where truth and falsehood compete. / They despise the law, seeking guilt, / Where the righteous perish in terrible injustice, / Where evil triumphs in its impunity" (Perepeliak, 2013: 282); "Why does a decent man suffer, / And an evil man, like cheese in butter, lives his life?.. And what do you do, God, You, like a leader in a pack?.." (Perepeliak, 2013: 282). Sometimes in theological poems the author feels despair of God's intercession and critically realizes the so-called "union of God with Satan", and this applies to the uncertain fate of every Ukrainian. The poet aptly uses Andriy Myastkivsky's phrase "I am looking for Ukraine in Ukraine". We agree with his opinion, because the famous Taras Shevchenko also raised this issue: "I will not leave a small trace / In our glorious Ukraine, / In ours - not my land" (Shevchenko, 1981: 307). Ivan Perepeliak in his poem "The Road to Calvary" continues this topical issue: "But who are we, call us Ukrainians! / Why do we live like this? / We will not share joy, but pain; In slavery we kill the exiles, / Exiles on their land from whence". The author addresses his like-minded people with pain: "Resurrect from sins, wake up, people! / Ukraine swineherds and Judas / Already led to Calvary for execution" (Perepelyak: 30). The believing poet is not afraid to oppose in the linguistic-poetic interpretation of anthroponyms completely polar, negative characters, which to some extent symbolize anxiety, misery, grief, betrayal, meanness, which, unfortunately, are present in our lives. Let's read Ivan Perepeliak's thoughts on this: "Oh God! Cain cried out desperately - / Now forever I am in a pack of wolves, who will withstand this punishment of the people" (Perepeliak, 2013: 123); "Or maybe at the same time we will forgive Judas / And we will justify the sin of fratricide" (Perepeliak, 2013: 124). The lines are filled with a kind of warning: "As long as the Jews live on earth, / As long as Cain marks you” (Perepeliak, 2013: 124); "Yes, we need earthly guidance, / But we need earthly miracles! And here money becomes the true God!" (Perepeliak, 2013: 575). In his monologue, Judas Iscariot directly emphasizes: "But he did not expel. Did he hope / that I would be cured / And called a friend... / Now I am a false apostle, a false messiah. I I have become a traitor forever" (Perepeliak, 2013: 576). A significant number of poetic contexts are devoted to the relationship between God and the lyrical hero. In the text of the poem "Antichrist", this character directly emphasizes: "In God's temple you want to sit like God, / Pretending to be God / And the road is paved with hypocrisy / Leads the blind to your satanic palace” (Perepeliak, 2013: 582). The negative actions of non-humans are shown in these actions: "A demagogue draws his sword; Mark the world under siege; You drive virtue into prison; You want to burn the white world to the background; Throw the grains of evil into the ashes" (Perepeliak, 2013: 582). That is why the author concludes so pessimistically about our society and even the whole world: "In despair the star will weep in the sky, / When all the wicked gather, / Who love pleasure more than God" (Perepeliak, 2013: 582). 


\section{Perepeliak - the citizen}

Finally, we are faced with the task of showing the conceptuality of the image of Ukraine in the language of Ivan Perepeliak, a citizen. A poet, he is a creative person, a citizen of his country can not exist outside the life of his country. In poetry, he and his characters are verbalized in multifaceted relationships with the people around him: grandfather, grandmother, father, stepfather, mother, wife, children, fellow villagers, and so on. We are not saying that his artistic imagination is rich in relationships with relatives (grandpa, grandma, father, mother, wife) but as well as with his village, rivers, fields, the word, with all that is called Ukraine. That is why we have such interesting apt titles of his poems. Therefore, this paradigm is often implemented in many artistic and semantic spheres, where the dominant concept is Ukraine: "Grandfather did not tell anyone about the offense / And he knew a lot about politics" (Perepeliak, 2013: 550); "My grandfather Fedosiy is a generous man. / I will give the land drop by drop for a lifetime; My grandfather's furrow rang; And I was destined / To continue the song with my great-great-grandfather" (Perepeliak, 2013: 260). "Baba Olena is in trouble - / She will find a job every day" (Perepeliak, 2013: 170). "The boy has no father... / And people did not call him an orphan / And he called him father; The father came to the boy at night" (Perepeliak, 2013: 253-254); "And then my father went to the plow. / Singing to the horizon sounded again". The author conveys the sympathy of his son to his mother: "I will embrace your mourning and understand: / My father became the earth so early" (Perepeliak, 2013: 264). The author's bitter feelings for the bright memory of his mother are embodied in the lines: "In the hospital the mother dies; Mom, be patient! Lighten up soon, / Don't close your eyes, please!" (Perepeliak, 2013: 564); "I feel like a guest in life, / When I come to your grave; I hurry to you every time, / Because, I know you look from that world" (Perepeliak, 2013: 565); "I will not say anything to my daughter: / She must understand everything herself; Did you know, daughter? That love is holy! / Let's cry together in the ashes" (Perepeliak, 2013: 134); "Uncles / Cheerful people roll cigarettes, / They are happy to treat a boy" (Perepeliak, 2013: 258). There are several dedications to relatives: the poet dedicated the poem "A heavy thunder rushed over the house..." to his sister Lida: "Over the house - the autumn fire of the stars, and eternity stopped like a moment" (Perepeliak, 2013: 273). Touched, he dedicates an intimate poem "I lean to the sun every night..." to his beloved wife Tony: "You appeared to me dressed in a storm; Our field lit up with fire flowers; The clouds in the sky lit up; the devils / burned their bridges in the ravines, / How my Sun came into orbit" (Perepeliak, 2013: 242).

\section{Conclusions}

In our opinion, the conceptualization of the paradigm "UKRAINE" - "WORLD" has a clear and concise toponymic pattern, which complements the relevant plot line of the work of art as "positive" and "negative" content. One can consider a number of linguistic concepts of I. Perepelyak as names of specific loci, symbols of the Ukrainian chronotope, words and concepts from the traditions of other peoples included in the Ukrainian language picture of the world, universal conceptual images, which are marked by the main features of Ivan Mikhailovich Perepeliak's poetic idiosyncrasy. Fruitfully using the conceptual toponym UKRAINE, the author often resorts to generalization and abstraction. Therefore, this keyword includes many contextual synonyms engraved in the words: "state", "country", "land", "mother-in-law", "land", "homeland" and so on. Our scientific research has identified the main vectors of conceptualization of this toponym in poetic language creation. For Ivan Perepeliak, the space of 
his native land is associated with favorite rivers, cities, villages, trees, flowers, in a word, concepts that are connected with the Ukrainian space. Therefore, in the bosom of this artistic and semantic plane, the poet emphasizes the love of freedom, self-affirmation of independence, the spirituality of the country as a living being.

\section{References}

Perepeliak I.M. (1983) Nad Suloiu-rikoiu: Poezii [Over the Sula River: Poetry]. Kharkiv [in Ukrainian].

Perepeliak I.M. (2013) Poezii ta poemy [Poetry and poems]. vol. 1. Kharkiv [in Ukrainian]. Perepeliak I.M. (2013) Poezii ta poemy [Poetry and poems]. vol. 2. Kharkiv [in Ukrainian]. Shevchenko T.H. (1981) Kobzar [Kobzar]. Kyiv [in Ukrainian]. 